\title{
Distribution and Spatial Variability of Some Physico-Chemical Properties and Various Forms of Potassium in Soils of Ashoknagar District of Madhya Pradesh, India
}

\author{
Sonu Kori ${ }^{1 *}$, S. K. Singh ${ }^{2}$, Rahul Morya ${ }^{1}$, and Subhash $^{3}$ \\ ${ }^{1}$ Soil Science and Agricultural Chemistry, College of Agriculture, \\ RVSKVV, Gwalior, (M.P.) 474002, India \\ ${ }^{2}$ Rajmata Vijayaraje Scindia Krishi Vishwa Vidyalaya, KV K. Gwalior, (M.P.) 474002, India \\ ${ }^{3}$ Division of Soil Physics, ICAR-Indian Institute of Soil Science, Bhopal (M.P.) 462038, India \\ *Corresponding author
}

\section{A B S T R A C T}

\begin{tabular}{|l|}
\hline Ke y w o r d s \\
$\begin{array}{l}\text { Soil properties, } \\
\text { potassium, } \\
\text { distribution }\end{array}$ \\
\hline Article Info \\
\hline $\begin{array}{l}\text { Accepted: } \\
\text { 05 June } 2020 \\
\text { Available Online: } \\
\text { 10 July 2020 }\end{array}$ \\
\hline
\end{tabular}

GPS based total 150 surface soil samples $(0-15 \mathrm{~cm})$ were collected from each block (30 samples) (namely; Mungaoli, Chanderi, Ishagarh, Ashoknagar and Sadora) of Ashok Nagar district. The samples were prepared and analyzed for different soil properties viz: soil texture (sand silt and clay), $\mathrm{pH}$, EC, soil organic carbon (SOC), Calcium carbonate different forms of potassium (i.e., water soluble, exchangeable, non- exchangeable lattice and total-K) used standard laboratory method. The result showed that range of physico-chemical properties: sand, silt and clay, $\mathrm{pH}, \mathrm{EC}, \mathrm{SOC}, \mathrm{CaCO}_{3}$ in the study region were varied from $36.6-56.7 \%, 03.9-38.0 \%, 25.4-42.4 \%, 7.8-8.6,0.3-0.6 \mathrm{dSm}^{-1}, 2.1-$ $7.2 \mathrm{~g} \mathrm{~kg}^{-1}$, and $0.5-3.5 \%$ and similarly value of different forms of potassium i.e. water soluble-K, exchangeable- $\mathrm{K}$, non- exchangeable- $\mathrm{K}$, lattice- $\mathrm{K}$ and total-K ranged from $9.4-26.8 \mathrm{mgkg}^{-1}, 101.2-$ $205.2 \mathrm{mgkg}^{-1}, 300.0-950.0 \mathrm{mgkg}^{-1}, 1.0-1.8 \%$ and $1.0-1.8 \%$ respectively. In general, soil organic carbon and clay content of the soils of study area shows positive relationship with all the forms of potassium, whereas, sand and soil $\mathrm{pH}$ show negative relationship. A highly significant and positive relationship was observed between different forms of $\mathrm{K}$, these relationships indicate that there existed equilibrium between these forms of $\mathrm{K}$ and depletion of one is instantly replenished by one or more of the other forms of $\mathrm{K}$.

\section{Introduction}

The global potassium demand for agriculture since the 1960s, the world population has doubled from three to seven billion, and this trend will persist in the coming decades. Because of this rapid expansion, a massive increase in crop production is required to meet the food and energy demands of future generations, while also preserving the ecological and energy related resources of our planet. Additionally, recent climate models predict that incidences and duration of drought and heat stress periods are increasing in many regions, negatively affecting our major crops, and thus our food security.

Therefore, major challenges for agriculture are to enhance crop yields in more resourceefficient systems and to stabilize plant 
development and yield formation under biotic and abiotic stress conditions (Reynolds et al., 2011). In this context, among the many plant nutrients, potassium $(\mathrm{K})$ plays a particularly crucial role in a number of physiological processes vital to growth, yield, quality, and stress resistance of all crops.

K constitutes about $2.1-2.3 \%$ of the earth's crust and thus is the seventh or eighth most abundant element (Schroeder, 1978; Wedepohl, 1995). As mineral soils contain $0.04-3 \% \mathrm{~K}$, the total $\mathrm{K}$ of the upper $0.2 \mathrm{~m}$ of most agricultural soils generally ranges between 10 and $20 \mathrm{~g} \mathrm{~kg}-1$ (Jackson, 1964; Sparks, 1987).

However, most of the soil K (90-98\%) is incorporated in the crystal lattice structure of minerals and thus not directly available for plant uptake. The availability of $\mathrm{K}$ differs greatly with soil type and is affected by physico-chemical properties of the soil. To simplify the complex $\mathrm{K}$ dynamics in soil, $\mathrm{K}$ in soil is often classified into four groups depending on its availability to plants: watersoluble, exchangeable, non-exchangeable and structural forms.

Water-soluble $\mathrm{K}$ is directly available for plants and microbes, and potentially subjected to leaching. Exchangeable $\mathrm{K}$ is electrostatically bound as an outer-sphere complex to the surfaces of clay minerals and humic substances (Barreet et al., 2008).

Both fractions are often considered to be easily available for crops. However, the size of both pools is very small. They make up only about $0.1-0.2 \%$ and $1-2 \%$ of the total $\mathrm{K}$ in soil, respectively (Sparks, 1987). Nonexchangeable and structural forms are considered to be slowly- or non-available $\mathrm{K}$ sources for plants. However, these pools may also contribute significantly to the plant supply in the long term (Pal et al., 2001).
The quantities of plant-available and nonavailable $\mathrm{K}$ in the soil vary greatly among soil types, and dynamic equilibrium reactions exist between the different pools of soil $\mathrm{K}$.

Most of the $\mathrm{K}$ in soil is in the structural form, mainly comprised of K-bearing primary minerals such as muscovite, biotite and feldspars. K-feldspars may directly release $\mathrm{K}$ to the soil solution, whereas interlayer $\mathrm{K}$ of micas is held tightly by electrostatic forces. Weathering of K-feldspars and micas inherited from soil parent materials produces secondary soil minerals which represent the potential sources of plant-available $\mathrm{K}$ in soils (Singh and Goulding, 1997).

The $\mathrm{K}$ in trioctahedral micas (such as biotite and phlogopite) is reported to be more readily released by weathering, and it has been suggested that application of biotite to Kdeficient soils may enhance the plantavailable $\mathrm{K}$ content of soil (Obornet et al., 2005). Formation of dioctahedral expansible $2: 1$ mineral from biotite is a distinct possibility that may enhance the amount of $\mathrm{K}$ in soil solution. It should be noted that weathering of K-containing primary minerals is very slow. Therefore, their sole addition to soil may not be beneficial for crop growth, especially when compared to soluble $\mathrm{K}$ fertilizers. Nevertheless, a number of recent investigations suggest that addition of rock $\mathrm{K}$ (K-containing primary minerals) materials may increase the long-term fertility of the soil by increasing the $\mathrm{K}$ depots (Sheng, 2005; Basak and Biswas, 2009).

Potassium is an essential nutrient element for all living organisms including plants and animals. It is univalent cation found in the largest concentration $(100-200 \mathrm{mMK})$ in the plant cell sap and so it is called a 'master cation'. Potassium is ionic $(\mathrm{K}+)$, free (not bound to any constituent) and mobile in the plants. 
The advent of information technology has provided tools like Global Positioning System (GPS), which help in collecting systematic set of geo-referenced samples and generating the spatial data about the distribution of nutrients (Sharma, 2004).

This will also help to monitor the changes in fertility status over a period of time as sampling sites can be revisited with help of GPS which is otherwise difficult in the random sampling (Sood, et al., 2003).

\section{Materials and Methods}

Ashoknagar district is located in the northern part of Madhya Pradesh, between the rivers Sindh and the Betwa. It comes under the northern part of Malwa plateau, though main part of its district lies in the Bundelkhand Plateau. The Coordinates of the district are $24^{\circ} 34^{\prime} 48^{\prime \prime} \mathrm{N}$ and $77^{\circ} 43^{\prime} 48^{\prime \prime} \mathrm{E}$ with average elevation of 507 meters above sea level and district covered area 3.12-million-hectare. On the basis of morphological observations, slope and other features, soils are well drained. It is in the plateau region and has an agricultural topography. The plateau is an extension of the Deccan Traps, formed between 60 and 68 million years ago at the end of the Cretaceous period.

The climate of Ashok Nagar district is subtropical. In summers, the temperature reaches $47^{\circ} \mathrm{C}$, while dropping to $4^{\circ} \mathrm{C}$ in the winter. The average daily temperature during the summer months is $35^{\circ} \mathrm{C}$, which typically rises to around $46{ }^{\circ} \mathrm{C}$ on a few days and annual average rainfall receives an of $140 \mathrm{~cm}$. soil study area are black, brown and bhatori (stony) soil. The volcanic, clay-like soil of the region owes its black color to the high iron content of the basalt from which it is formed. Total 150 surface $(0-15 \mathrm{~cm})$ soil samples (GPS based,) were collected with the help of soil auger from cultivator's fields of five blocks (namely; Mungaoli, Chanderi, Ishagarh, Ashoknagar and sadora) of Ashok Nagar district. At each location soil was collected from four places, mixed thoroughly and reduces to get a representative sample by quartering.

Percent distribution of sand, silt and clay was determined by Bouyoucos hydrometer method (Bouyoucos, 1962). The organic carbon (Walkley and Black 1934) and calcium carbonate (Jackson, 1973). Soil and electrical conductivity determination by using standard methods.

Water soluble potassium was estimated in 1:5, soil, water ratio suspension as described by Black (1965). Exchangeable potassium was determined by Flame photometer in the extract of $1 \mathrm{~N}$ neutral ammonium acetate solution in 1:5 soil: Extract ratio as described by Black (1965). Non-exchangeable K: $1 \mathrm{~N}$ boiling $\mathrm{HNO}_{3}$ extractable potassium was estimated flame photometrically in 1:10, soil: acid suspension boiled for 10 minutes as described by Black, (1965). Total potassium was estimated flame photometrically by digesting soil with hydrofluoric $(48 \%)$ and perchloric (70-72\%) acid in platinum crucible by the method outlined by Black, (1965) and Lattice K: Estimated by difference between total $\mathrm{K}$ and sum of water soluble exchangeable and non-exchangeable potassium.

The descriptive statistics like minimum, maximum, mean, standard deviation, coefficient of variation (CV) and skewness were obtained. The Pearson correlation coefficients were used to evaluate the correlations between available micronutrients with soil properties. The normal frequency distribution of data was verified by the Kolmogorov-Smirnov (K-S) test. These statistical parameters were calculated with SPSS version 21.0. 


\section{Results and Discussion}

\section{Physico-chemical properties}

Soil texture of five blocks (namely, Mungaoli, Chanderi, Isagarh, Ashoknagar and Sadora) of Ashoknagar district value are presented in table no1. In the study area of soil texture value showed (table 1 and figure 2) sand, silt and clay varied from $36.6-56.7 \%, 3.9-38.0 \%$ and $25.4-42.4 \%$, with the mean value of $47.1 \%, 17.0 \%$ and $35.9 \%$,respectively,

However, maximum mean content of sand $(49.4 \%)$, silt $(24.3 \%)$ and clay $(38.0 \%)$ were observed recorded in Chanderi, Isagarh, sadora block, respectively, whereas minimum content of sand (43.9\%), silt (12.8\%) and clay $(31.8 \%$ ) were observed in Sadora, Isagarh and Sadora block, respectively. Usually clay soil is considered as more preferable for agricultural crops.

Soil texture is considered an important parameter. It influences the soil properties like water holding capacity, bulk density, soil structure and hydraulic conductivity that control the flow dynamics of water, nutrients and salts in soil. Similar result recorded by (Santra et al., 2008) Soil pH was ranged between 7.2 - 8.6 with the average value of 8.0 (Table1). However, pH value in different villages of Mungaoli, Chanderi, Isagarh, Ashoknagar, and Sadora block having an average value of $7.9,7.9,8.0,8.1$ and 7.9 respectively.

The soils were natural to slightly alkaline in reaction, this indicated that the soil from the studied region was good for farming practices. Similar, result were recorded (Ravikumar and Somashekar, 2013, Shukla et al., 2016 and Subhash et al., 2017) indicating the existence of a variety of soils that are slightly natural to slightly alkaline nature. Maximum mean value of soil $\mathrm{pH}$ (8.1) was observed in Ashoknagar block whereas minimum value (7.9) noted in Sadora block of Ashoknagar district. Higher mean $\mathrm{pH}(>8.6)$ in some of the samples of Ashoknagar district indicate towards the fact that the soils are infested with alkalinity.

Soil properties change with time and space of the small scales to large scales, which are influenced by intrinsic properties (such as soil parent materials) and non-inherent characteristics such as management, fertilizer and crop rotation (Quine \& Zhang, 2002; Godwin \& Miller, 2003).

EC in Ashoknagar district varied value from $0.3-0.6$ with the average value of $0.5 \mathrm{dSm}^{-1}$ (Table 1). Highest value of EC $\left(0.6 \mathrm{dSm}^{-1}\right)$ was observed in Korwas village of Isagarh block whereas minimum value $\left(0.3 \mathrm{dSm}^{-1}\right)$ was found in Shyampur village of Mungaoli block of Ashoknagar district. Even though, soil conductivity is influenced by many factors, high conductivities are usually associated with clay rich soil and low conductivities are associated with sandy and gravelly soils.

The EC of soil water suspension (1:2) ranged between $0.3-0.6 \mathrm{dSm}^{-1}$ it showed a considerable variation with variation in topography of soil. On the basis of limit suggested all samples were $\left(\mathrm{EC}<0.45 \mathrm{dSm}^{-1}\right)$ in the range of normal category of salt content, the soil shaving soluble salt concentration in safer limit for satisfactory plant growth, similar findings were reported Bharteey et al., (2017).

Calcium carbonate of studied area of Ashoknagar district was found in the range of $0.5-3.5 \%$ under different villages with an average value of $1.8 \%$ (Table 1). However, calcium carbonate status in different villages of Mungaoli, Chanderi, Isagarh, Ashoknagar, and Sadora block varied from 0.5-3.0, 0.5- 
$3.5,0.5-2.5,0.5-3.0$ and $0.5-2.5 \%$, with a mean value of $1.7,1.8,1.8,1.9$ and $1.7 \%$ respectively. Highest content of calcium carbonate $(3.5 \%)$ was noted in Barodiya village of Chanderi block of Ashoknagar district. However, this clearly indicates that the most of the soils of was normal in nature in respect of calcium carbonate content by (Subhash et al., 2019).

\section{Status of different forms of potassium}

Status of water soluble-K in studied area of Ashoknagar district was presented in Table 2. It ranged from 9.4-26.8 mg kg-1 under different blocks with an average value of 17.6 $\mathrm{mg} \mathrm{kg}^{-1}$ and contributed only $0.124 \%$ of total$\mathrm{K}$. However, water soluble- $\mathrm{K}$ content in five blocks (namely, Mungaoli, Chanderi, Isagarh, Ashoknagar, and Sadora) of Ashoknagar district.

Varied from 9.5-25.5, 12.0-26.8, 11.5-26.6, 9.4-23.6 and 10.1-26.1 mg kg-1 with an average value of $16.4,20.3,18.3,16.1$ and17.3 $\mathrm{mg} \mathrm{kg}^{-1}$, respectively. Maximum average value of water-soluble $\mathrm{K}\left(28.8 \mathrm{mg} \mathrm{kg}^{-1}\right)$ was observed in Chanderi block whereas minimum value $\left(9.4 \mathrm{mg} \mathrm{kg}^{-1}\right)$ was found in Ashoknagar block of Ashoknagar district.

Result on the same line with different soil types have also been reported by Padole and Mahajan, (2003) and Chandra sekharrao and Krishnamurthy, (2007).It is clear from result that the sand fraction of soils was negatively and significantly correlated with water soluble $\mathrm{K}$. This may be due to less content of potassium bearing minerals in sand fractions or due to the fact that the potassium in soil is utilized by crop more easily and is also subjected to erosion losses.

The exchangeable- $\mathrm{K}$ statusin five blocks (namely, Mungaoli, Chanderi, Isagarh, Ashoknagar, and Sadora) of Ashoknagar district varied from 102.0-117.0, 125.5202.2, 127.2-211.0,101.5-187.2 and 107.5$205.0 \mathrm{mg} \mathrm{kg}^{-1}$ with an average value of 109.7 , 166.2, $172.1,154.5$ and $160.0 \mathrm{mg} \mathrm{kg}^{-}$ ${ }^{1}$ respectively.Maximum average value of exchangeable- $\mathrm{K} \quad\left(205.0 \quad \mathrm{mg} \quad \mathrm{kg}^{-1}\right)$ was observed in Sadora block whereas minimum value (101.2 $\mathrm{mg} \mathrm{kg}^{-1}$ ) was found in Mungaoli block of Ashoknagar district. Kaskar et al., (2001) and Padole and Mahajan, (2003) also reported that exchangeable $\mathrm{K}$ contributed same line towards total K.The variation in exchangeable potassium content among the soil samples may be attributed to differential release of potassium from non-exchangeable and lattice potassium as well as variation in labile pool due to potassium fertilization.

Status of non-exchangeable-K in soils of five blocks ((namely, Mungaoli, Chanderi, Isagarh, Ashoknagar, and Sadora) of Ashoknagar district. was found in the range of 300.0-950.0 mg kg-1 under different blocks with an average value of $148.8 \mathrm{mg} \mathrm{kg}^{-1}$ and contributed to $4.320 \%$ of total-K. However, non-exchangeable - $\mathrm{K}$ content in five blocks (namely, Mungaoli, Chanderi, Isagarh, Ashoknagar, and Sadora) of Ashoknagar district. varied from 315.1-860.2, 340.0940.0, 350.4-940.0,300.0-850.0 and 300.1$950.0 \mathrm{mg} \mathrm{kg}^{-1}$ with an average value of 564.8 , 648.3, 691.1,570.7and 601.1 $\mathrm{mg} \mathrm{kg}^{-}$ ${ }^{1}$ respectively. Maximum average value of non-exchangeable- $\mathrm{K}\left(950.0 \mathrm{mg} \mathrm{kg}{ }^{-1}\right)$ was observed in Sadora block whereas minimum value $\left(300.0 \mathrm{mg} \mathrm{kg} \mathrm{kg}^{-1}\right)$ was found in Ashoknagar block of Ashoknagar district.

Lattice- K under studied area of five blocks of Ashoknagar district was found in the range of 1.0-1.8\% under different blocks with an average value of $1.3 \%$ which accounts more than $90 \%(94.7 \%)$ of the total $-\mathrm{K}$. However, lattice - K content in five blocks (namely, Mungaoli, Chanderi, Isagarh, Ashoknagar, and Sadora) of Ashoknagar district. 
Varied from $1.0-1.6,1.0-1.7,1.0-1.8,1.1-$ 1.5 and $1.0-1.6 \%$ with an average value of $1.3,1.3,1.4,1.2$ and $1.4 \%$, respectively. Maximum average value of lattice- K (1.8\%) was observed in Isagarh block whereas minimum value $(1.0 \%)$ found in Mungaoli block of Ashoknagar district. Kaskar et al., (2001) and Padole and Mahajan, (2003) also reported that lattice $\mathrm{K}$ contributed same line towards total- K. Status of total- K under studied area of five blocks of Ashoknagar district was noticed in the range of $1.0-1.8$ $\%$ under different blocks with an average value of $1.4 \%$. However total-K content in five blocks (namely, Mungaoli, Chanderi, Isagarh, Ashoknagar and Sadora) of Ashoknagar district varied from 1.0-1.6, 1.0 $1.7,1.1-1.8,1.1-1.6$ and $1.1-1.7 \%$ with an average value of $1.4,1.4,1.5,1.4$ and $1.4 \%$, respectively. Maximum average value of total- K (1.8\%) was observed in Isagarh block whereas minimum value $(1.0 \%)$ found in Mungaoli block of Ashoknanar district.

\section{Relationship between soil properties and different forms of potassium in study area}

Results pertaining to indicated that the soil $\mathrm{pH}$ showed negative and highly significantly correlation with non-exchangeable $-\mathrm{K}$ ( $\mathrm{r}=-$ $0.217 * *)$, while correlation of $\mathrm{pH}$ with other forms of the potassium was found nonsignificant (table 3).EC had positive and highly significantly correlation with all the forms of potassium, except water soluble-K.

Organic carbon content of the soils exhibited significant to highly significant positive correlation with water soluble $\mathrm{K}(\mathrm{r}=0.482 * *)$, exchangeable- $\mathrm{K} \quad\left(\mathrm{r}=0.725^{* *}\right)$, nonexchangeable-K $\quad\left(\mathrm{r}=0.733^{* *}\right), \quad$ lattice-K $\left(\mathrm{r}=0.330^{* *}\right)$ and Total-K $\left(\mathrm{r}=0.168^{*}\right)$. Associations of soil parameter calcium carbonate with lattice and Total $-\mathrm{K}$ negative and highly significant. Sand had negative and significant correlation with exchangeable-K, lattice- $\mathrm{K}$ and total-K. The results indicated that the soil parameter silt did not show any relationship with any forms of potassium Soil parameter clay had significant to highly significant of positive correlation with all studied forms of potassium. Water soluble- K was highly and significantly correlated with exchangeable potassium, non-exchangeable potassium, lattice potassium and total potassium. Similar results were also reported by Das et al., (2000) and Setia and Sharma, (2004). The better correlation of these forms of potassium with other forms indicates that the water-soluble potassium was governed by the other forms of potassium like nonexchangeable and total potassium.

Exchangeable- $\mathrm{K}$ with soil properties showed that exchangeable $-\mathrm{K}$ was highly significantly and positively correlated with EC, organic carbon, and clay content. Which might be due to the fact that with increase in organic matter in soils, the clay-humus complex becomes more active there by providing more exchange sites and access to $\mathrm{K}$. These results are in agreement with the findings of Mishra and Shrivastava, (1991), Sonar and Patil, (1996), Das et al., (2000), Singh et al., (2001) and Sharma et al., (2009).

Negative and significant coefficient of correlation of sand particles was observed with exchangeable-K. The sand fraction was significantly but negatively correlated with exchangeable potassium this may be due to less content of potassium bearing minerals in sand fractions. Sharma and Sharma, (2001) Arora and Chahal, (2003), Sharma et al., (2009) and Saini and Grewal, (2014), also observed similar type observation in their studies Non-exchangeable- $K$ with soil properties showed that it was highly significantly and positively correlated with EC, organic carbon and clay content whereas negatively high significant correlated with $\mathrm{pH}$ and $\mathrm{CaCO}_{3}$ non- significant. 
Int.J.Curr.Microbiol.App.Sci (2020) 9(7): 362-373

Table.1 Distribution of some physico-chemical in soils of different blocks of Ashoknagar district

\begin{tabular}{|c|c|c|c|c|c|c|c|c|}
\hline Soil properties & & pH & EC & SOC & $\mathrm{CaCO}_{3}$ & Sand & Silt & Clay \\
\hline \multirow{5}{*}{$\begin{array}{c}\text { Mungaoli } \\
(\mathrm{n}=\mathbf{3 0})\end{array}$} & Range & $7.1-8.6$ & $0.3-0.6$ & $2.12-6.8$ & $0.5-3$ & $40-54.1$ & $12.2-23.8$ & $30.5-40.8$ \\
\hline & Mean & 7.9 & 0.5 & 3.8 & 1.8 & 46.1 & 17.0 & 37.4 \\
\hline & SD & 0.38 & 0.1 & 1.3 & 0.6 & 3.7 & 3.3 & 2.7 \\
\hline & $\mathrm{CV}$ & 4.81 & 16.1 & 32.6 & 33.4 & 8.0 & 19.5 & 7.1 \\
\hline & Skew. & -0.98 & 0.5 & 0.6 & 0.0 & 0.3 & 0.6 & -0.9 \\
\hline \multirow{5}{*}{$\begin{array}{c}\text { Chanderi } \\
(\mathbf{n}=30)\end{array}$} & Range & $7.2-8.6$ & $0.4-0.6$ & $2.8-6.8$ & $0.5-3.5$ & $32.5-58.0$ & $5.8-32.7$ & $27.6-42.8$ \\
\hline & Mean & 7.9 & 0.5 & 4.1 & 1.9 & 49.6 & 14.3 & 37.2 \\
\hline & SD & 0.44 & 0.1 & 1.3 & 0.7 & 5.5 & 9.0 & 3.7 \\
\hline & $\mathrm{CV}$ & 5.57 & 11.0 & 31.6 & 37.0 & 11.0 & 62.6 & 9.9 \\
\hline & Skew. & -0.42 & 0.4 & 0.7 & 0.0 & -1.3 & 1.3 & -0.8 \\
\hline \multirow{5}{*}{$\begin{array}{c}\text { Isagarh } \\
(\mathbf{n}=30)\end{array}$} & Range & $7.5-8.4$ & $0.4-0.7$ & $2.4-7.8$ & $0.5-2.5$ & $39.6-55.7$ & $3.9-19.6$ & $35.2-42.6$ \\
\hline & Mean & 8.0 & 0.5 & 4.4 & 1.8 & 48.1 & 12.9 & 39.5 \\
\hline & SD & 0.26 & 0.1 & 1.5 & 0.5 & 5.0 & 5.1 & 1.7 \\
\hline & $\mathrm{CV}$ & 3.32 & 15.2 & 34.4 & 30.7 & 10.4 & 40.0 & 4.3 \\
\hline & Skew. & -0.21 & 1.1 & 0.7 & -0.1 & -0.2 & -0.4 & -0.6 \\
\hline \multirow{5}{*}{$\begin{array}{c}\text { Ashoknagar } \\
\quad(n=30)\end{array}$} & Range & $7.5-8.5$ & $0.4-0.6$ & $2.3-5.8$ & $0.5-3$ & $38.3-54.1$ & $7.8-24.6$ & $28.4-42.4$ \\
\hline & Mean & 8.1 & 0.4 & 3.9 & 1.9 & 45.7 & 16.4 & 38.0 \\
\hline & SD & 0.24 & 0.1 & 1.0 & 0.6 & 4.4 & 5.1 & 3.5 \\
\hline & $\mathrm{CV}$ & 2.97 & 11.0 & 26.1 & 29.9 & 9.7 & 30.8 & 9.1 \\
\hline & Skew. & -0.83 & 1.6 & 0.5 & -0.4 & 0.4 & -0.2 & -1.2 \\
\hline \multirow{5}{*}{$\begin{array}{c}\text { Sadora } \\
(n=30)\end{array}$} & Range & $7.2-8.4$ & $0.4-0.6$ & $2.8-6.9$ & $0.5-2.5$ & $30.6-54.7$ & $10.1-38$ & $25.8-42.3$ \\
\hline & Mean & 7.9 & 0.5 & 4.3 & 1.8 & 42.3 & 23.5 & 34.9 \\
\hline & SD & 0.32 & 0.1 & 1.2 & 0.5 & 4.9 & 8.3 & 5.4 \\
\hline & $\mathrm{CV}$ & 4.03 & 11.0 & 26.5 & 29.7 & 11.6 & 35.5 & 15.4 \\
\hline & Skew. & -0.30 & 0.8 & 0.5 & -0.4 & 0.3 & 0.2 & -0.2 \\
\hline \multirow[t]{2}{*}{ Whole district } & Range & $7.2-8.6$ & $0.3-0.6$ & $2.1-7.2$ & $0.5-3.5$ & $36.6-56.7$ & $3.9-38.0$ & $25.4-42.4$ \\
\hline & Mean & 8.0 & 0.45 & 4.42 & 1.8 & 47.1 & 17 & 35.9 \\
\hline
\end{tabular}


Table.2 Distribution of different forms of potassium in soils of different blocks of Ashoknagar district

\begin{tabular}{|c|c|c|c|c|c|}
\hline Forms of potassium & Total -K (\%) & Lattice $-\mathrm{K}(\%)$ & $\begin{array}{c}\text { Non- } \\
\text { exchangeable - K: }\end{array}$ & Exchangeable -K & $\begin{array}{c}\text { Water } \\
\text { soluble-K }\end{array}$ \\
\hline Name of block & Range (mean) & Range (mean) & $\begin{array}{l}\text { Range } \\
\text { (mean) }\end{array}$ & $\begin{array}{l}\text { Range } \\
\text { (mean) }\end{array}$ & $\begin{array}{l}\text { Range } \\
\text { (mean) }\end{array}$ \\
\hline Mungaoli(n=30) & $1.01-1.6(1.4)$ & $1.0-1.6(1.3)$ & $\begin{array}{c}315.1-860.2 \\
(564.8)\end{array}$ & $102.0-177.0(152.2)$ & $\begin{array}{c}9.5-25.5 \\
(15.9)\end{array}$ \\
\hline Chanderi(n=30) & $1.0-1.7(1.4)$ & $1.0-1.7(1.3)$ & $\begin{array}{c}340.0-940.3 \\
(623.9)\end{array}$ & $\begin{array}{c}122.5-202.25 \\
(166.2)\end{array}$ & $\begin{array}{l}12.0-26.8 \\
(13.0)\end{array}$ \\
\hline $\begin{array}{l}\text { Isagarh } \\
(\mathbf{n}=\mathbf{3 0})\end{array}$ & $1.1-1.8(1.5)$ & $1.0-1.8(1.4)$ & $\begin{array}{c}350.4-940.0 \\
(691.1)\end{array}$ & $127.2-211.0(172.1)$ & $\begin{array}{c}11.5-26.3 \\
(16.4)\end{array}$ \\
\hline Ashoknanar(n=30) & $1.1-1.6(1.4)$ & $1.1-1.52(1.2)$ & $\begin{array}{c}300.0-850.2 \\
(570.7)\end{array}$ & $101.5-187.0(154.5)$ & $\begin{array}{l}9.4-23.6 \\
(15.3)\end{array}$ \\
\hline $\begin{array}{l}\text { Sadora } \\
\text { (30) }\end{array}$ & $1.1-1.7(1.4)$ & $1.0-1.58(1.4)$ & $300.1-950.0(601.1)$ & $107.5-205.0(160.0)$ & $\begin{array}{c}10.0-26.1 \\
(17.1)\end{array}$ \\
\hline As a whole district & $1.0-1.8(1.4)$ & $1.0-1.8(1.3)$ & $\begin{array}{c}300.0-950.0 \\
(614.8)\end{array}$ & $101.2-205.0(161.1)$ & $\begin{array}{c}9.4-26.8 \\
(17.6)\end{array}$ \\
\hline
\end{tabular}

Table.3 Relationship between soil properties and different forms of potassium

\begin{tabular}{|c|c|c|c|c|c|}
\hline Soil Parameters & WS-K & Ex.-K & NEx $-\mathbf{K}$ & Lattice-K & Total-K \\
\hline pH & -0.054 & -0.022 & $-0.217 * *$ & -0.052 & -0.089 \\
\hline EC & 0.122 & $0.221 * *$ & $0.236 * *$ & 0.196* & $0.286 * *$ \\
\hline OC & $0.482 * *$ & $0.725 * *$ & $0.733 * *$ & $0.350 * *$ & $0.168^{*}$ \\
\hline $\mathrm{CaCO}_{3}$ & -0.143 & -0.156 & -0.050 & $-0.274 * *$ & $-0.295^{* *}$ \\
\hline Sand & -0.089 & $-0.162 *$ & -0.156 & $-0.172 *$ & $-0.175^{*}$ \\
\hline Silt & -0.036 & -0.058 & -0.045 & -0.081 & -0.014 \\
\hline Clay & $0.248 * *$ & $0.447 * *$ & $0.389 * *$ & $0.301 * *$ & $0.255^{* * *}$ \\
\hline
\end{tabular}

** Correlation is significant at the 0.01 level, * Correlation is significant at the 0.05 level

Abbreviations, $\mathrm{N}$ Ex $-\mathrm{K}=$ Non-exchangeable $-\mathrm{K}$, Ex.- $\mathrm{K}=$ exchangeable $-\mathrm{K}$, WS- $\mathrm{K}=$ Water soluble $-\mathrm{K}$

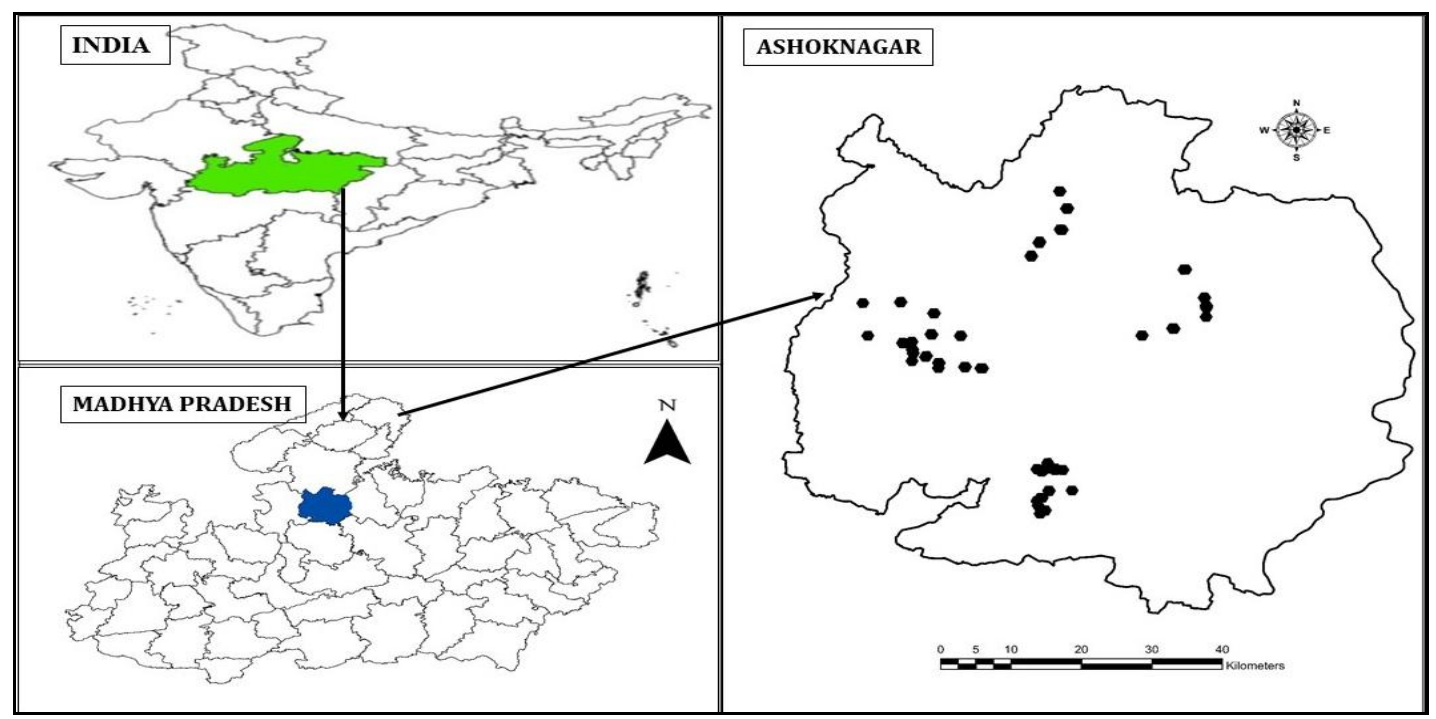

Figure.1 Location of study area 


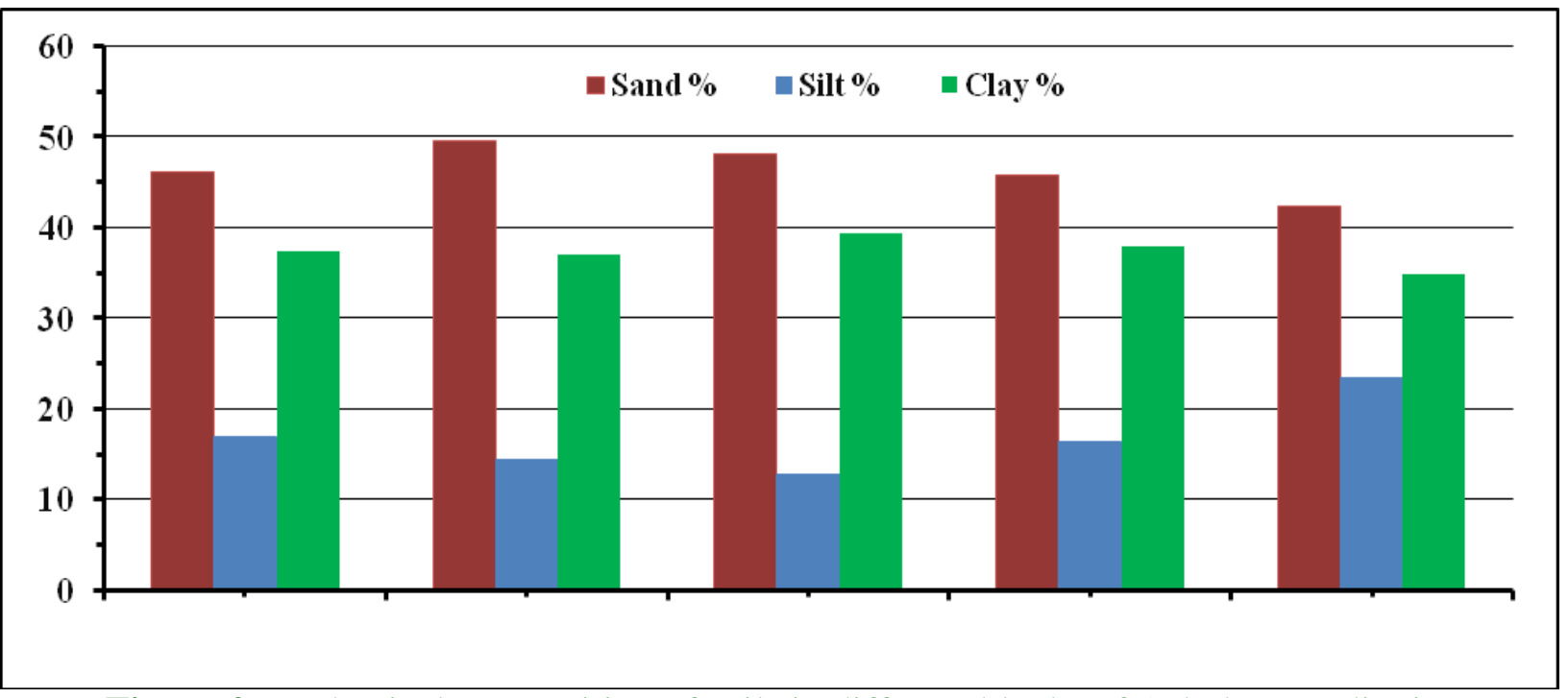

Figure.2 Mechanical composition of soils in different blocks of Ashoknagar district

Chand and Swami, (2000) Kaskar et al., (2001) and Sharma et al., (2009) also reported similar results with different soil type. Total$\mathrm{K}$ was highly significantly and positively correlated with EC, and clay content whereas negatively non- significant and significant correlated with $\mathrm{CaCO}_{3}$ and sand and significantly and positively corrected with organic carbon and negatively correlated with $\mathrm{pH}$, sand and silt. These relationships confirmed that the finer fractions of the soils are in primary sources of potassium in the soils of Ashoknagar. The results also point out that the light textured soils would be depleted easily than heavy textured for native potassium. Therefore, continuous monitoring of soil potassium status is essential in these types of soils. Chand et al., (2000) also observed positive correlation between total $\mathrm{K}$ and organic carbon, silt and clay content.

From the correlation matrix given in previous chapter table 3 , it is clear from result that the sand fraction of soils was negatively and significantly correlated with water soluble $\mathrm{K}$. This may be due to less content of potassium bearing minerals in sand fractions or due to the fact that the potassium in soil is utilized by crop more easily and is also subjected to erosion losses.
The soil texture of Ashoknagar district varied from sandy clay loam to clay loam. Soils were neutral to slightly alkaline in nature with having normal EC and calcium carbonate content. Soil organic carbon was found in the range of 2.1-7.2 $\mathrm{g} \mathrm{kg}^{-1}$ under different villages with the average Value of $4.4 \mathrm{~g} \mathrm{~kg}^{-1}$. Most of the soil samples showed low category of organic carbon status $\left(<0.5 \mathrm{~kg}^{-1}\right)$.

The amount of water soluble, exchangeable and non-exchangeable- $\mathrm{K}$ in different villages of study region found ranged from $9.4-26.8$, 101.2 - 205.0 and 300.0 - $950.0 \mathrm{mg} \mathrm{kg}^{-1}$ with the mean value of $17.6,101.1$ and $614.8 \mathrm{mg}$ $\mathrm{kg}^{-1}$ respectively. These forms contributed $0.1,1.4$ and $4.3 \%$ towards total-K. whereas, Lattice and total-K found in the range of 1.01.8 and $1.0-1.8 \%$ with the mean value of 1.3 and $1.4 \%$ respectively. Lattice $-\mathrm{K}$ contributed maximum (94.7\%) towards total$\mathrm{K}$.

In general, soil organic carbon and clay content of the soils of study areas shows positive relationship with all the forms of potassium, whereas, sand and soil $\mathrm{pH}$ show negative relationship. A highly significantly and positively relationship was observed between different forms of $\mathrm{K}$, these 
relationships indicate that there existed equilibrium between these forms of $\mathrm{K}$ and depletion of one is instantly replenished by one or more of the other forms of $\mathrm{K}$.

\section{References}

Arora S. and Chahal, DS. (2003) Distribution of Available Potassium in Benchmark Soils of Punjab in Relation to Soil Characteristics. J. of Potassium Res. 19: 41-44.

Barreet P., Montagnier C., Chenu, C., Abbadie, L. and Velde, B. (2008) Clay minerals as a soil Potassium reservoir: observation and quantification through X-ray diffraction. Plant Soil; 302:21320.

Basak, BB. and Biswas, DR. (2009) Influence of potassium solubilizing microorganism (Bacillus mucilaginosus) and waste mica on potassium uptake dynamics by sudan grass (Sorghum vulgare Pers.) grown under two Alfisols. Plant Soil; 317:23555.

Bharteey, PK. Singh YV. Sukirtee Sharma P.K. Kumar M and Kumar RA (2017). Available Macro Nutrient Status and their Relationship with Soil PhysicoChemical Properties of Mirzapur District of Uttar- Pradesh, India. Int. J. Curr. Microbiol. App. Sci. 6(7): 28292837.

Black, CA. (1965). Methods of soil analysis. PartII. Am. Soc. Agron. Madiosn, Wiscousin U.S.A

Bouyoucos, GJ. 1962. Hydrometer method improved for making particle size analysis of soils. Agron. J. 54: 464-465.

Chand, S and Swami, BN. (2000) different forms of potassium in some important soil's association of Bharatpur district of Rajasthan. J. of Potassium Res. 16: $59-61$.

Chandra sekhara Rao, C. and Krishnamurthy,
V. (2007). Quantity-intensity relationship of potassium in fule-cured virginia tobacco soils of Khammam district, Andhra Predesh. Journal of the Indian Society Soil Science, 55 (2): 212-215.

Das, K, Dipak, Sarkar and Nayak, DC. (2000). Forms of potassium and their distribution in some soils representing red and laterite ecosystem of West Bengal. J. of Potassium Res. 16: $1-6$.

Dudal, R. (1965). Dark clay soils of tropical and subtropical regions. Dark clay soils of tropical and subtropical regions.

Godwin, RJ., \& Miller, PCH. (2003). A review of the technologies for mapping within-field variability. Biosystems engineering, 84(4), 393-407.

Jackson, ML. (1964) Chemical composition of soils. In: Bear FE, editor. Chemistry of the soil. NewYork: Van Nostrand Reinhold; p. 71-141.

Kaskar, DR., Salvi, V. G., Mayekar, BS. and Dabke, DJ. (2001) Forms of potassium, their interrelationship and relationship with other soil properties of Inceptisols of west coast of Maharashtra. J. of Potassium Res. 17: 23 - 27.

Kenchanagouda, SK., 1977. Effect of continuous irrigation on physical, chemical and mineralogical properties of the soils of Tungabhadra project command area. Ph.D., Thesis, Univ. Agric. Sci., Bangalore.

Mishra, MK. and Srivastava, P.C. (1991) Depth wise distribution of forms of potassium in some soil profiles of Garhwal Himalayas. J. of Potassium Res. 7(2): 75-84

Obornet I. Andrist-Range,1 .Y., Askekaard, M., Grant, C.A., Watson, C. A. and Edwards, A.C.(2005) Critical aspects of potassium management in agricultural systems. Soil Use Manage; 21:102-12.

Padole, VR. and Mahajan, SB. (2003) Status 
and release behavior of potassium in some swell- shrink soils of Vidarbha, Maharashtra. J. Mah. Agric.Univ. 28:37.

Pal, DK., Srivastava, P., Durge, S.L., Bhattacharyya, T. (2001) Role of weathering of fine-grained micas in potassium management of Indian soils. Appl ClaySci ; 20:39-52.

Quine, TA., \& Zhang, Y. (2002). An investigation of spatial variation in soil erosion, soil properties, and crop production within an agricultural field in Devon, United Kingdom. Journal of Soil and Water Conservation, 57(1), 5565.

Ravikumar P and Somashekar RK. 2013. Evaluation of nutrient index using organic carbon, available $\mathrm{P}$ and available $\mathrm{K}$ concentrations as a measure of soil fertility in Varahi River basin, India Proceedings of the International Academy of Ecology and Environ. Sci. 3(4):330-343.

Reynolds, M., Bonnett, D., Chapman, S.C., Furbank, R.T., Manes, Y.and Mather, D.E. (2011) Raising yield potential of wheat. I. Overview of a consortium approach and breeding strategies. J Exp Bot; 62:439-52.

Saini, JG. and Grewal, KS. (2014) Vertical distribution of different forms of potassium and their relationship with different soil properties in some Haryana soil under different crop rotation. Department of soil science, CCS Haryana agricultural university; India. Plant and Agriculture Research, article, 1(2).

Santra, AK., Sen, S., \& Chakraborty, N. (2008). Study of heat transfer augmentation in a differentially heated square cavity using copper-water nanofluid. International Journal of Thermal Sciences, 47(9), 1113-1122.

Schroeder, D. (1978). Structure and weathering of potassium containing minerals. In: Proc.11th Congr. Int. Potash Inst.

Setia, RK. and Sharma, KN. (2004) Vertical distribution of chemicals pools of potassium and their relationship with potassium nutrition of wheat under long- term differential fertilization. Journal of the Indian Society Soil Science, 52 (4) :469-473.

Shalini K., Devenda HS, Dhindsa SS, et al., 2003. Studies on causes and possible remedies of water and soil pollution in Sanganer town of Pink City. Indian Journal of Environmental Sciences, 7(1): 47-52.

Sharma, A., Jalali, V.K., Arya, V.M. and Rai, Pradeep (2009) Distribution of various forms of potassium in soils representing intermediate zone of Jammu region. Journal of the Indian Society Soil Science, 57 (2):205-208.

Sharma, PK. (2004) Emerging technologies of remote sensing and GIS for the development of spatial data infrastructure. J. Indian Soc. Soil Sci. 52: 384-406.

Sharma, V and Sharma, KN. (2001) Distribution of different Forms of Potassium in Potato Growing Soils of Punjab. J. of Potassium Res. 17: 112 115.

Sheng, XF. (2005) Growth promotion and increased potassium uptake of cotton andrape by a potassium releasing strain of Bacillus edaphicus. Soil Biol. Biochem. 2005 37:1918-22.

Shukla, AK., Behera, SK., Lenka, NK., Tiwari, PK., Prakash, C., Malik, RS. and Chaudhary, SK. (2016) Spatial variability of soil micronutrients in the intensively cultivated Trans-Gangetic Plains of India. Soil and Tillage Research. 163, 282-289.

Singh, B. and Goulding, KWT. (1997) Changes with time in the potassium 
content and phyllosilicates in the soil of the Broadbalk continuous wheat experiment at Rothamsted. Eur. J. Soil Sci.; 48:651-9.

Singh, Kaptan; Malik, RVS. and Singh, V (2001) Distribution of Forms of Potassium in Alluvial Soils. J. of Potassium Res.17: 116-118.

Sonar, KR. and Patil, YM. (1996) Forms of potassium influenced by Geology and Physiography of the soil in Maharastra. J. of Potassium Res. 12 (3): 230 - 236.

Sood, A., Patel, L. B. and Sharma P. K. (2003) N, P and K Status of SubMountainous Tract of Punjab.

Sparks, DL. (1987). potassium dynamics in soils. Adv Soil Sci.6:1-63.

Subhash, Tagore GS., Kulhare PS. and Shukla AK. (2019) Mapping of Spatial Pattern of Micronutrients in Soils of Harda District of Madhya Pradesh through
Geo-statistical Tool in Arc GIS Environment. Int. J. Curr. Microbiol. App. Sci 8(2): 52-63.

Subhash, Tagore GS., Nath D., Mohanty M. and Sinha NK. (2017); Evaluation of Variation in Macronutrients of Soils in Harda District, Madhya Pradesh, India A Geostatistical Approach. Advances in Research.11(5): 1-13.

Walkley A. and Black, IA. (1934). Estimation of soil organic carbon by chromic acid titration method. Soil Science37:29-38.

Wedepohl, KH., (1995). The composition of the continental crust. Eochim Cosmo chim Acta; 59:1217-32.

Yadav, RL. and Meena, MC. (2009) Available micronutrients status and their relationship with soil properties of degana soil series of Rajasthan. Journal of the Indian Society Soil Science.

\section{How to cite this article:}

Sonu Kori, S. K. Singh, Rahul Morya, and Subhash. 2020. Distribution and Spatial Variability of Some Physico-Chemical Properties and Various Forms of Potassium in Soils of Ashoknagar District of Madhya Pradesh, India. Int.J.Curr.Microbiol.App.Sci. 9(07): 362-373.

doi: https://doi.org/10.20546/ijcmas.2020.907.039 